\title{
Kidney and Ureter Neoplasm
}

National Cancer Institute

\section{Source}

National Cancer Institute. Kidney and Ureter Neoplasm. NCI Thesaurus. Code C7514.

A benign or malignant, primary or metastatic neoplasm affecting the kidney and ureter. 